\title{
Effectiveness of Video Assisted Teaching on Labour Process and Knowledge of Primigravidae
}

\section{Pushpaveni NP* and Joslin L Almeida}

Department of Nursing, Government College of Nursing, Bangalore, India

*Corresponding author: Pushpaveni NP, Department of Nursing, Government College of Nursing, Bangalore, India, Tel: 09844364122, E-mail: pushpaveni42@gmail.com

Received date: February 19, 2018; Accepted date: February 28, 2018; Published date: March 6, 2018

Copyright: (c) 2018 Pushpaveni NP, et al. This is an open-access article distributed under the terms of the Creative Commons Attribution License, which permits unrestricted use, distribution, and reproduction in any medium, provided the original author and source are credited.

\begin{abstract}
Background and objectives: Pregnancy is a unique, exciting and often joyous time in a woman's life. It is said that labor can be one of the most tiring and energetic experiences of a woman's life. Primigravidae is the one who is more anxious about labor because of the lack of previous exposure to labor. In order to educate and encourage the primigravidae, to improve their knowledge regarding labor process, the study was conducted to evaluate the Effectiveness of video assisted teaching regarding knowledge on labor process among primigravidae attending antenatal OPD at selected maternity hospital, Bengaluru.
\end{abstract}

Methods: Pre-experimental design, with purposive sampling method was used. Information was collected from 40 primigravidae regarding labor process using the structured interview schedule. VAT was implemented and posttest was conducted after 7 days to find the effectiveness.

Results: Majority of respondents were from 19-26 years were Hindus, belongs to nuclear family, completed middle school education, occupation being home maker, monthly income below Rs. 3,000, attained menarche at 19-21 years; between 32-34 weeks of gestation. Major information had from family members/relatives. Regarding effectiveness of VAT, the overall mean knowledge score in the pre-test was $37.9 \%$ and $79.5 \%$ in the post test with enhancement of $41.5 \%$ and it was significant at $5 \%$ level. Analysis of socio-demographic variables showed significant association between age in years, occupation, age at menarche, gestational age with knowledge score at $5 \%$ level $(P>0.05)$.

Interpretation and conclusion: Overall findings showed that pre-test knowledge scores were found to be $37.9 \%$ and after VAT, knowledge or primigravidae was enhanced by $41.5 \%$ regarding labor process. Hence the result has proved that VAT was effective in improving the knowledge of primigravidae on labor process.

Keywords: Pregnancy; Child birth; Labor process; Uterus

\section{Introduction and Background}

Pregnancy is a unique, exiting and often joyous time in a woman's life. It is said that labor can be one of the most tiring and energetic experiences of a woman's life. Primigravidae is one who is more anxious about labor because of the lack of exposure to labor. In order to educate and encourage the primigravidae, to improve their knowledge regarding labor process the study was conducted [1]. Pregnant women in general and first time mothers in particular are provided with a vast amount of information. Many women especially first time mothers attend antenatal classes which prepare them for labor and delivery [1].

Labor is called labour because of the amount of physical work it involves. It is said that labor is one of the most tiring energetic experiences of a women's life. Some people say it is like running a marathon. Now no one would consider entering a marathon race without a proper preparation and training specifically for it. From the time women know and are ready to believe that she is pregnant, she could be preparing for this big event [2].
Knowledge regarding the pregnancy and labor has the positive influence on the antenatal women to take adequate care of her and in turn leads to better compliance during labor process, there by leading to natural child birth. The child birth experience is a complex event and important life experience for women. Prepared child birth reduces the fear and tension of the child birth by education and relaxation [3]. In India most mothers have poor knowledge on antenatal and intranatal care available to them. Illiteracy, poverty and lack of communication and transport facility make them vulnerable to serious consequences [4].

Studies related to maternal and infant mortality and morbidity suggested that prenatal education programme should be developed and conducted by health educators because this education would have its goal awareness on the part of pregnant women and their behaviour affects the health of their infants [5]. Primigravidae mother is the one who is more anxious about labor because of the lack of information about the labor process. If she is provided with adequate information regarding labor process and her role in labor, it will empower her during labour and have control over labor process [6].

Knowledge regarding the pregnancy and labor has a positive influence on the antenatal women, to take adequate care of her and intern leads to better compliance during labor process, there by leading 
to natural child birth. The child birth experience is a complex event and important life experience for women. Studies show that women who are prepared and use the comfort measures from child birth preparation classes by using Video Assisted Teaching make the birthing process easier and have a shorter labor if all factors are favourable.

\section{The objectives of the study}

To assess the pre-test level of knowledge regarding labor process among primigravidae attending antenatal OPD of selected maternity hospitals, Bangalore.

To evaluate the effectiveness of Video assisted Teaching regarding labor process among primigravidae attending antenatal OPD of selected hospitals, Bangalore.

To find out the association between post-test knowledge scores regarding labor process among primigravidae attending antenatal OPD of selected hospitals, Bangalore and their selected socio demographic variables.

\section{Hypotheses}

$\mathrm{H}_{1}$ : There will be a significant increase in the mean post-test knowledge scores of primigravidae regarding labor process.

$\mathrm{H}_{2}$ : There will be a significant association between the post-test knowledge scores of primigravidae regarding labor process and selected socio demographic variables.

\section{Assumptions}

- Primigravidae will have some knowledge regarding labor process.

- Video assisted teaching can increase the knowledge of Primigravidae regarding labor process and improves labor outcome.

\section{Variables of the study}

Independent variables: Video assisted teaching on labor process.

Dependent variables: Knowledge of primigravidae regarding labor process.

Socio-demographic variables: Age, Educational status, Type of family, Religion, Occupation, family income, age at menarche, age at marriage, gestational age and Source of Information.

\section{Delimitation}

The study is delimited to 40 primigravidae attending antenatal OPD of selected maternity hospitals, Bangalore.

\section{Conceptual framework}

The conceptual framework of the study parameter is based on Orem's selfcare model. The study was aimed at developing and evaluating the effectiveness of Video assisted teaching on knowledge regarding labor process. According to Orem, adequate knowledge about labor process improves the health of the mother and have positive labor outcome.

\section{Methodology}

\section{Research approach and design}

An evaluative approach was adopted and pre experimental with one group pre-test and post-test design was used for this study. Study was conducted in vanivilas maternity hospital, Bangalore. The primigravidae were selected from antenatal OPD of Vanivilas Maternity Hospital, Bangalore. Forty primigravidae were selected by purposive sampling technique.

\section{Criteria for selection of samples}

\section{Inclusion criteria}

- Primigravidae who have completed 32 weeks of gestation

- Primigravidae who are willing to participate in the study.

\section{Exclusion criteria}

- Primigravidae with high risk pregnancy.

- Primigravidae who are not present at the time of data collection.

\section{Tool used for the study}

A structured interview schedule and video assisted teaching material were prepared to collect the data to achieve objectives of the study. The tool was developed by the investigator after reviewing the related literature and guidance from the experts in the field.

Section I: Socio demographic schedule consists of 10 items which include Age, Educational status, Type of family, Religion, Occupation, family income, age at menarche, age at marriage, gestational age and Source of Information on labor process.

Section II: Structured interview schedule regarding Knowledge on labor process consists of 34 items of multiple choices.

Section III: Video assisted teaching material consists of 3 components. They are Anatomy and physiology of uterus, Normal pregnancy, Normal labor process.

\section{Procedure for data collection}

Formal administrative permission was obtained from the Medical superintendent of Vanivilas hospital and written consent was taken from the subjects. Socio-demographic data was collected from subjects through structured interview schedule. The pre-test was conducted among primigravidae to assess the pre- test knowledge level regarding labor process.

The facility for video screening of the teaching was arranged in the comfortable room. Videos were projected with step by step explanation regarding anatomy and physiology of the uterus, normal pregnancy and normal labor process. Video Assisted teaching was screened through projector for 40 minutes.

After one week Post test was conducted to assess the knowledge of subjects regarding labor process through the same structured interview schedule which was used for pre-test. 
Citation: Pushpaveni NP, Almeida JL (2018) Effectiveness of Video Assisted Teaching on Labour Process and Knowledge of Primigravidae. Adv

Page 3 of 5

\section{Results}

\section{Findings of the study}

Based on the age equal proportion (50\%) of the respondents belongs to the age group of $19-22$ years and $23-26$ years. $30 \%$ of the respondents completed middle school education. $77 \%$ were homemakers, $62.5 \%$ attained menarche between the ages of $12-13$ years.

$55 \%$ were married between the age of $19-21$ years. $70 \%$ were belonged to 32-34 weeks of gestation. The overall post-test mean knowledge found to be $79.5 \%$ with SD of $6.8 \%$ (Table 1 ).

\begin{tabular}{|c|c|c|c|c|c|c|c|c|}
\hline \multirow{3}{*}{ No. } & \multirow{3}{*}{ Knowledge aspects } & \multicolumn{6}{|c|}{ Respondent knowledge (\%) } & \multirow[t]{3}{*}{ Paired 't' Test } \\
\hline & & \multicolumn{2}{|c|}{ Pre-test } & \multicolumn{2}{|c|}{ Post-test } & \multicolumn{2}{|c|}{ Enhancement } & \\
\hline & & Mean & SD & Mean & SD & Mean & SD & \\
\hline I & Normal pregnancy & 33.2 & 12.7 & 77.1 & 16.1 & 43.9 & 18.4 & $15.09^{*}$ \\
\hline II & Stages of labor & 36 & 12.8 & 79.3 & 10.2 & 43.3 & 14 & $19.56^{*}$ \\
\hline III & $\begin{array}{l}\text { Signs of labor and pain } \\
\text { management }\end{array}$ & 45.4 & 16.9 & 83.8 & 13.9 & 38.3 & 16.1 & $15.05^{*}$ \\
\hline IV & $\begin{array}{l}\text { Position, pushing } \\
\text { techniques and nutrition }\end{array}$ & 38.6 & 15.9 & 78.9 & 13.2 & 40.2 & 14.7 & $17.30^{*}$ \\
\hline \multicolumn{2}{|c|}{ Combined } & 37.9 & 10.3 & 79.5 & 6.8 & 41.5 & 9.5 & $27.63^{*}$ \\
\hline
\end{tabular}

Table 1: Aspect wise mean pre- test and post-test knowledge of primigravidae attending antenatal $\operatorname{OPD}\left[{ }^{*}\right.$ Significant at $5 \%$ level, $\mathrm{t}(0.05,39$ df) $=1.96, \mathrm{~N}=40]$.

The highest mean $83.8 \%$ seen in signs of labor \& pain management aspect. The overall pre-test mean knowledge score was $37.9 \%$ \& posttest value was $79.5 \%$ with enhancement of $41.5 \%$ (Table 2 ).

\begin{tabular}{|c|c|c|c|c|c|c|}
\hline \multirow{3}{*}{$\begin{array}{l}\text { Knowledge } \\
\text { level }\end{array}$} & \multirow[b]{3}{*}{ Category } & \multicolumn{4}{|c|}{ Classification of subjects } & $\begin{array}{l}X^{2} \\
\text { value }\end{array}$ \\
\hline & & \multicolumn{2}{|l|}{ Pre-test } & \multicolumn{2}{|l|}{ Post-test } & \\
\hline & & Number & Percent & Number & Percent & \\
\hline Inadequate & $-<50 \%$ & 29 & 72.5 & 0 & 0 & \\
\hline Moderate & $51-75 \%$ & 11 & 27.5 & 13 & 32.5 & \\
\hline Adequate & $>75 \%$ & 0 & 0 & 27 & 67.5 & $56.17^{*}$ \\
\hline Total & - & 40 & 100 & 40 & 100 & - \\
\hline
\end{tabular}

Table 2: Classification of subjects regarding knowledge on labor process.

Paired ' $t$ ' test shows statistical significance at $5 \%$ level $(\mathrm{p}<0.05)$ establishing the impact of video assisted teaching on labor process among primigravidae (Tables 3 ).

\begin{tabular}{|l|l|l|l|l|l|l|}
\hline \multirow{2}{*}{ Statistics } & \multirow{2}{*}{ Max. score } & \multicolumn{4}{|l|}{ Subject's knowledge } & \multirow{2}{*}{$\begin{array}{l}\text { Paired 't' } \\
\text { test }\end{array}$} \\
\cline { 3 - 6 } & & Mean & SD & Mean\% & SD\% & \\
\hline Pre-test & 34 & 12.93 & 3.5 & 37.9 & 10.3 & \multirow{2}{*}{$27.63^{*}$} \\
\hline Post-test & 34 & 27.03 & 2.3 & 79.5 & 6.8 & \\
\hline Enhancement & 34 & 14.13 & 3.2 & 41.5 & 9.5 & - \\
\hline *Significant at 5\% level, t(0.05,39 df)=1.96 & & & & \\
\hline
\end{tabular}

Table 3: Over all pre-test and post-test mean knowledge score on labor process.

Findings related to association between post-test knowledge score and socio-demographical variables shows significant association between age, occupation, age at menarche, gestational age and knowledge scores. There was no significant association between educational status, age at marriage, religion, family income/month, type of family, sources of knowledge on labor process and post-test knowledge score (Table 4).

\begin{tabular}{|c|c|c|c|c|c|c|c|c|}
\hline \multirow[b]{3}{*}{ Socio demographic variables } & \multirow[b]{3}{*}{ Category } & \multirow[b]{3}{*}{ Sample } & \multicolumn{6}{|c|}{ Subject's knowledge } \\
\hline & & & \multicolumn{2}{|c|}{ Moderate } & \multicolumn{2}{|c|}{ Adequate } & $\begin{array}{l}\text { Chi } \\
\text { Square }\end{array}$ & $P$ value \\
\hline & & & $\mathrm{N}$ & $\%$ & $\mathrm{~N}$ & $\%$ & & \multirow[b]{3}{*}{$P<0.05$} \\
\hline \multirow[b]{2}{*}{ Age (years) } & $19-22$ & 20 & 3 & 15 & 17 & 85 & $5.58^{*}$ & \\
\hline & $23-26$ & 20 & 10 & 50 & 10 & 50 & $d f=1$ & \\
\hline
\end{tabular}


Citation: Pushpaveni NP, Almeida JL (2018) Effectiveness of Video Assisted Teaching on Labour Process and Knowledge of Primigravidae. Adv Practice Nurs 3: 148. doi:10.4172/2573-0347.1000148

Page 4 of 5

\begin{tabular}{|c|c|c|c|c|c|c|c|c|}
\hline & Combined & 40 & 13 & 32.5 & 27 & 67.5 & - & - \\
\hline \multirow[b]{5}{*}{ Educational Status } & Primary School & 10 & 6 & 60 & 4 & 40 & 4.67 & \multirow[b]{4}{*}{$P>0.05$} \\
\hline & Middle School & 12 & 3 & 25 & 9 & 75 & NS & \\
\hline & High School & 10 & 2 & 20 & 8 & 80 & $d f=3$ & \\
\hline & Pre-University & 8 & 2 & 25 & 6 & 75 & - & \\
\hline & Combined & 40 & 13 & 32.5 & 27 & 67.5 & - & - \\
\hline \multirow[b]{4}{*}{ Occupation } & Home Maker & 31 & 8 & 25.8 & 23 & 74.2 & $6.88^{*}$ & \multirow[b]{3}{*}{$\mathrm{P}<0.05$} \\
\hline & Daily Wages/coolie & 5 & 4 & 80 & 1 & 20 & $d f=2$ & \\
\hline & Private Employee & 4 & 1 & 25 & 3 & 75 & - & \\
\hline & Combined & 40 & 13 & 32.5 & 27 & 67.5 & - & - \\
\hline \multirow[b]{3}{*}{ Age at menarche } & Dec-13 & 25 & 5 & 20 & 20 & 80 & $4.75^{*}$ & \multirow[b]{3}{*}{$P<0.05$} \\
\hline & $14-15$ & 15 & 8 & 53.3 & 7 & 46.7 & $d f=1$ & \\
\hline & Combined & 40 & 13 & 32.5 & 27 & 67.5 & - & \\
\hline \multirow[b]{3}{*}{ Age at marriage } & $19-21$ & 22 & 7 & 31.8 & 15 & 68.2 & $0.01^{\mathrm{NS}}$ & \multirow[b]{3}{*}{$P>0.05$} \\
\hline & $22-24$ & 18 & 6 & 33.3 & 12 & 66.7 & $d f=1$ & \\
\hline & Combined & 40 & 13 & 32.5 & 27 & 67.5 & - & \\
\hline \multirow[b]{3}{*}{ Gestational age in weeks } & $32-34$ & 28 & 6 & 21.4 & 22 & 78.6 & $5.22^{*}$ & \multirow[b]{3}{*}{$P<0.05$} \\
\hline & $36-38$ & 12 & 7 & 58.3 & 5 & 41.7 & $d f=1$ & \\
\hline & Combined & 40 & 13 & 32.5 & 27 & 67.5 & - & \\
\hline \multirow[b]{4}{*}{ Religion } & Hindu & 20 & 7 & 35 & 13 & 65 & 0.16 & \multirow[b]{4}{*}{$P>0.05$} \\
\hline & Muslim & 14 & 4 & 28.6 & 10 & 71.4 & NS & \\
\hline & Christian & 6 & 2 & 33.3 & 4 & 66.7 & $d f=2$ & \\
\hline & Combined & 40 & 13 & 32.5 & 27 & 67.5 & - & \\
\hline \multirow[b]{3}{*}{ Family income/month } & Rs.2000-3000 & 22 & 8 & 36.4 & 14 & 63.6 & $0.33^{\mathrm{NS}}$ & \multirow[b]{2}{*}{$P>0.05$} \\
\hline & Rs.4000-6000 & 18 & 5 & 27.8 & 13 & 72.2 & $d f=1$ & \\
\hline & Combined & 40 & 13 & 32.5 & 27 & 67.5 & - & - \\
\hline \multirow[b]{3}{*}{ Type of family } & Nuclear & 24 & 8 & 33.3 & 16 & 66.7 & $0.02^{\mathrm{NS}}$ & \multirow[b]{3}{*}{$P>0.05$} \\
\hline & Joint & 16 & 5 & 31.2 & 11 & 68.8 & $d f=2$ & \\
\hline & combined & 40 & 13 & 32.5 & 27 & 67.5 & - & \\
\hline \multirow{5}{*}{$\begin{array}{l}\text { Source of information on labor } \\
\text { process }\end{array}$} & Print media & 2 & 0 & 0 & 2 & 100 & $2.02^{\mathrm{NS}}$ & \multirow[b]{4}{*}{$P>0.05$} \\
\hline & Health personnel & 6 & 1 & 16.7 & 5 & 83.8 & $d f=3$ & \\
\hline & Family members & 21 & 8 & 38.1 & 13 & 61.9 & - & \\
\hline & Others & 11 & 4 & 36.4 & 7 & 63.6 & & \\
\hline & Combined & 40 & 13 & 32.5 & 27 & 67.5 & - & - \\
\hline
\end{tabular}

Table 4: Association between socio-demographic variables and post-test knowledge score. 


\section{Discussion}

A report of findings is never sufficient to convey their significance. The meaning that researchers give to the results plays a right and important role in the report. The discussion Section is devoted to a thoughtful and insightful analysis of the finding, leading to a discussion of their clinical and theoretical utility [7]. In this study the primigravidae who had socio demographic and economic conditions of maternal factors such as age, parity, quality of antenatal care and previous obstetric history was influenced the risk factors during antenatal period. Similar study conducted by Nair, et al. found that the socio demographic valuables influences the quality antenatal care and found to be more at risk of having low birth basics [8].

Education plays an important role. In this study the primigravidae who had high schools and above education level were able to follow recommended dietary practices during antenatal period. Pan, et al. conducted a co-relational study found that the Pregnant Women who had education could able to take recommended dietary allowances with increase intake of protein, calcium and Iron [9]. Related to type of family in this study the nuclear family comprises $60 \%$ and joint family 40\%. Similar findings in descriptive study conducted by Agarwal and others $67.9 \%$ respondents were belonged to joint family [10].

Related to socio-economic status, study revealed that there is impact of socio-economic states of knowledge, opinion and practices of antenatal mothers regarding antenatal care (Kumar, et al.). In this study it is found that socioeconomic status had no impact on knowledge of antenatal mothers regarding antenatal care [11]. The effectiveness of birth-preparedness program was conducted by $\mathrm{Mc}$ Pherson, et al. revealed that it can positively influence knowledge and intermediate health outcomes similar report has been found in this study as there is improvement is experimental group's perinatal outcome [12].

In this study it is found that who had education program had used good delivery method and initiated breast feeding within half an hour of delivery compared to control group who had not received education. Similar study was conducted by Chien, et al. found the effectiveness of delivery method and timing of breast feeding initiation on breastfeeding outcomes in Taiwan [13].

In this study primigravidae who had attended the birth process classes had knowledge and less anxious about labor. Similar study conducted by Artieta, et al. shows the results that the antenatal mothers who had birth preparedness classes had good coping mechanism and confident [14]. The primigravidae who had video assisted teaching on labor process had adequate knowledge. Similar study conducted by Maimburg, et al. shows the improved knowledge on birth process [15]. A quasi experimental study was conducted by Malatha, et al. showed the results that the pregnant women who had child birth education programme associated with increasing in maternal knowledge regarding antenatal care and labor process. The same findings found in the present study [16].

\section{Conclusion}

The pre-test knowledge score among majority primigravidae was inadequate and post-test knowledge score found adequate. There was significant enhancement in knowledge of primigravidae after conducting video assisted teaching on labor process. There was significant association found between post-test knowledge score and selected socio- demographic variables such as age, occupation, age at menarche, gestational age at $\mathrm{P}=0.05$ level. The findings of the study reveals that there was no significant association found between posttest knowledge score and selected socio- demographic variables such as educational status, age at marriage, religion, family monthly income, type of family, source of information on labour process at $0.05 \%$ level.

\section{Recommendations}

- A replication of present study can be conducted on larger samples.

- A similar study can be conducted in different hospital settings such as antenatal wards, antenatal clinics in community area.

- A comparative study can be done between Urban and Rural antenatal mothers.

- Manuals and information booklets may be developed to enhance the knowledge on labor process.

\section{References}

1. Renkert S, Nutbeam D (2001) Opportunities to improve maternal health literacy through antenatal education Health Promot Int 16: 381-388.

2. Kardel KR, Henriksen T, Iversen PO (2010) No effect of energy supply during child birth on delivery outcomes in nulliparous women: A randomized double -blind placebo controlled trial. J Obstet Gyenaecol 30: 248-252.

3. Murira N, Munjanja SP, Zhanda I, Lindmark G, Nystrom L (1996) Health education for pregnancy care in Harare. Cent Afr J Med 42: 297-301.

4. Kumar S, Joshi ID (2001) The outcome and experience of first pregnancy in relation to the mother's child birth knowledge. J Indian medical Association 16: 113-126.

5. Jerrold S, Greenberg (1997) The need for prenatal education. Health Edu J 36: 84-87.

6. Barbara W (2007) Child birth education programmes: The relationship between confidence and knowledge. Birth 11: 103-108.

7. Basavanthappa BT (2007) Nursing Reseach 2nd edn Jaypee brothers New Delhi: pp 92-155.

8. Nair NS, Rao RS, Chandrashekar S, Acharya D, Bhat HV (2000) Socio demographic and maternal determinants of lowbirth weight: A multivariate approach. Indian J Paeditr 67: 9-14.

9. Panwar B, Punia D (1998) Nutrients intake of rural pregnant women of Haryana state, Northeren India: Relationship between income and education. Int J Food Sci Nutr 49: 391-395.

10. Agarwal S, Sethi V, Srivathsava K, Jah PK (2010) Birth preparedness and complication readiness among slum women in Indore city in India. J Health Popul Nutr 28: 383-391.

11. Kumar R, Singh MM, Kaur M (1997) Impact of health centre availability on utilization of maternity care and pregnancy outcome in a rural area of Haryana. J Indian Med Asso 95: 448-450.

12. McPherson RA, Khadka N, Moore JM, Sharma M (2006) Birth preparedness programme effective. J Health Popul Nutr 24: 479-488.

13. Chien LY, Tai CJ (2007) Effect of delivery method \& timing of breast feeding initiation. Birth 34: 123-130.

14. Artieta PI, Paz-Pascual C, Grandes G, Remiro-Fernandezdegamboa G, Odriozola-Hermosilla I, et al. (2010) The benefit of antenatal education for the child birth process. Nurs Res 59: 194-202.

15. Maimburg RD, Varth M, Durr L, Hvidman L, Olson J (2010) Randomised trial of structured antenatal training session to improve the birth process. BJOG 117: 921-928.

16. Malatha A, Hauck Y (2007) Development and evaluation of a child birth education program for Malawian women. J Adv Nurs 60: 67-68. 